\title{
Improving civil-military coordination in humanitarian logistics: the challenge
}

\author{
Graham E. Heaslip ${ }^{1 *}$ and Elizabeth Barber² \\ 'School of Business, Galway Mayo Institute of Technology, Ireland \\ ${ }^{2}$ School of Business, University of New South Wales \\ Australian Defence Academy, Australia
}

\begin{abstract}
Within the emerging field of humanitarian logistics, the civil-military logistical interface has achieved only minimal attention in academic literature even though most western nations have a civil-military division within their defence departments. Due to fundamental differences between humanitarian and development agencies and international military forces in terms of the principles and doctrines guiding their work, their agendas, operating styles and roles, the area of civil-military logistical coordination in humanitarian relief has proven to be more difficult than other interagency relationships. This paper presents recent research that proposes a model for logistics requirements in humanitarian operations, taking account of where and how civil-military involvement can be most effective and efficient across all phases of humanitarian operations. Interviews were conducted with key personnel in humanitarian and military organisations. The model proposed here, appears to be robust and workable in a range of geopolitical and operational circumstances. We show that the greatest impact of military involvement is most beneficial in the initial crucial life sustaining days immediately after natural disasters. In contrast in manmade complex emergencies, military assistance to the logistical provision of aid is more beneficial when widespread military expertise is provided.
\end{abstract}

Keywords: civil-military cooperation; complex emergencies; coordination; humanitarian logistics; natural disasters; supply chain management

(C) De Gruyter Open Sp. z 0.0 .

\section{INTRODUCTION}

The purpose of this paper is to advance the thought and practice on improving coordination, in the context of humanitarian logistics. The article is conceptual in nature, drawing on a topical literature review, interviews, and it also draws on the authors' previous experiences from research projects and as practitioners in the field. This paper elucidates humanitarian logistics needs across all phases of humanitarian operations. It investigates where and how civil-military involvement can be most effective and efficient. The paper aims to further the understanding of planning and carrying out logistics operations in the complex area of humanitarian operations. It also investigates the impacts of military logistical assistance to humanitarian operations.

Humanitarian and military logistics are closely aligned. But what is meant by the term 'logistics'? Within the humanitarian community, the following is a frequently quoted definition:

'The process of planning, implementing and controlling the efficient, cost-effective flow and storage of goods and materials as well as related information, from the point of origin to the point of consumption for the purpose of meeting the end beneficiary's requirements.' (Thomas and Mizushima, 2005: 60)

From this definition, it can be seen that the humanitarian logistics community has adopted the 're-labelling' perspective of Larson and Halldórsson (2004) and Larson et al. (2007) which suggests that the field previously described as 'logistics' is now referred to within commerce and industry as 'supply chain (or network) management' (SCM/SNM). Importantly, by viewing 'logistics' in this way, the humanitarian approach is actually closely aligned with 
a generic military understanding of the concept. For example, both the Australian Defence Forces (ADF) and the members of the North Atlantic Treaty Organisation (NATO) define logistics as:

'The science of planning and carrying out the movement and maintenance of forces. In its most comprehensive sense, the aspects of military operations which deal with:

a. design and development, acquisition, storage, transport, distribution, maintenance, evacuation and disposition of materiel

b. transport of personnel;

c. acquisition or construction, maintenance, operation and disposition of facilities;

d. acquisition or furnishing of services; and

e. medical and health service support.' (1997: 103)

It is argued (Kovács and Tatham, 2009; Heaslip, 2011), therefore, that the military forces of many countries are not only well prepared to conduct operations in the field of combat, but also in the generically similar circumstances that reflect aftermath of a disaster or an emergency. In particular, many military forces are, as a result of their ability to move quickly with appropriate equipment and trained manpower, ideally suited to offer assistance in the logistic arena (Barber, 2011).

The paper is organised into five sections. The next section provides some conceptual background on humanitarian logistics and supply chain management theory. A short section describing the methodology for this paper is advanced before an examination of the different phases in humanitarian logistics and the introduction of a proposed model. This is followed by an illustration of military involvement in humanitarian logistics and the presentation of the increased cooperation of military logistics support. Finally, the paper closes with a discussion, including implications for practitioners, and suggestions for future research.

\section{Conceptual background to humanitarian logistics}

For the purposes of this paper, the term 'humanitarian logistics' will be used in the sense defined in the previous section by both Thomas and Mizushima (2005) and the ADF/NATO (1997). In line with this broad definition, van Wassenhove (2006) has estimated that some $80 \%$ of the expenditure of non-government organisations (NGOs) in humanitarian operations is related to logistics. Whilst there are clear distinctions between United Nations (UN) Agencies such as the World Food Programme (WFP), and World Health Organisation (WHO); the Red Cross movement; and NGOs, for convenience the latter abbreviation will be used to refer to all such entities except where the context dictates a differentiation.

The majority of funds donated to humanitarian operations through NGOs responding to natural disasters are directed to logistics purposes. Development aid since 2004 to 2011 has increased approximately 60\% (at current prices and exchange rates, last updated $4^{\text {th }}$ April, 2012) for total Official Development Assistance (ODA) of Development Assistance Committee (DAC) countries (OECD, 2012). This increase in aid is becoming more necessary as not only do a significant number of natural disasters and complex emergencies ${ }^{1}$ devastate the world each year, but there is also broad agreement that the situation is worsening (see Figure 1).

The annual expenditure of the NGO community exceeds \$AU 20 billion (Tatham and Pettit, 2010). This leads to the critical questions of how this vast sum can be expended more efficiently and effectively. Figure 1 demonstrates that the average death toll per natural disaster is reducing (EM-DAT, 2010), and consequently, the number of those affected by natural disasters has dramatically increased, which highlights the real logistic challenge, delivering appropriate sustenance to the living. Given that the ODAs are increasing their financial assistance to support the increases in the number of surviving victims, it is no surprise that the ODAs are demanding more efficiency. Logistics presents a vehicle in which efficiencies can be realised.

It is, however, fully accepted that logistics is but one element of the totality of the preparation and response effort. Indeed, this recognition mirrors many militaries, such as, Ireland, Finland, UK, and Australia's approach to the development and maintenance of a military capability that has adopted a framework that reflects the Resource Based View (RBV) of a firm (Barney, 1991). The adopted RBV framework describes eight components of such a military capability (personnel, collective training, organisation, major systems, supplies, facilities, support, and command and management (DOD, 2007) and, in doing so, emphasises the need to ensure the inter- and intraorganisational coherence that is fundamental to the commercial concept of supply network management (Richey et al., 2010). 
Figure 1. Natural disaster summary 1900-2011 (source: EM-DAT, 2011)

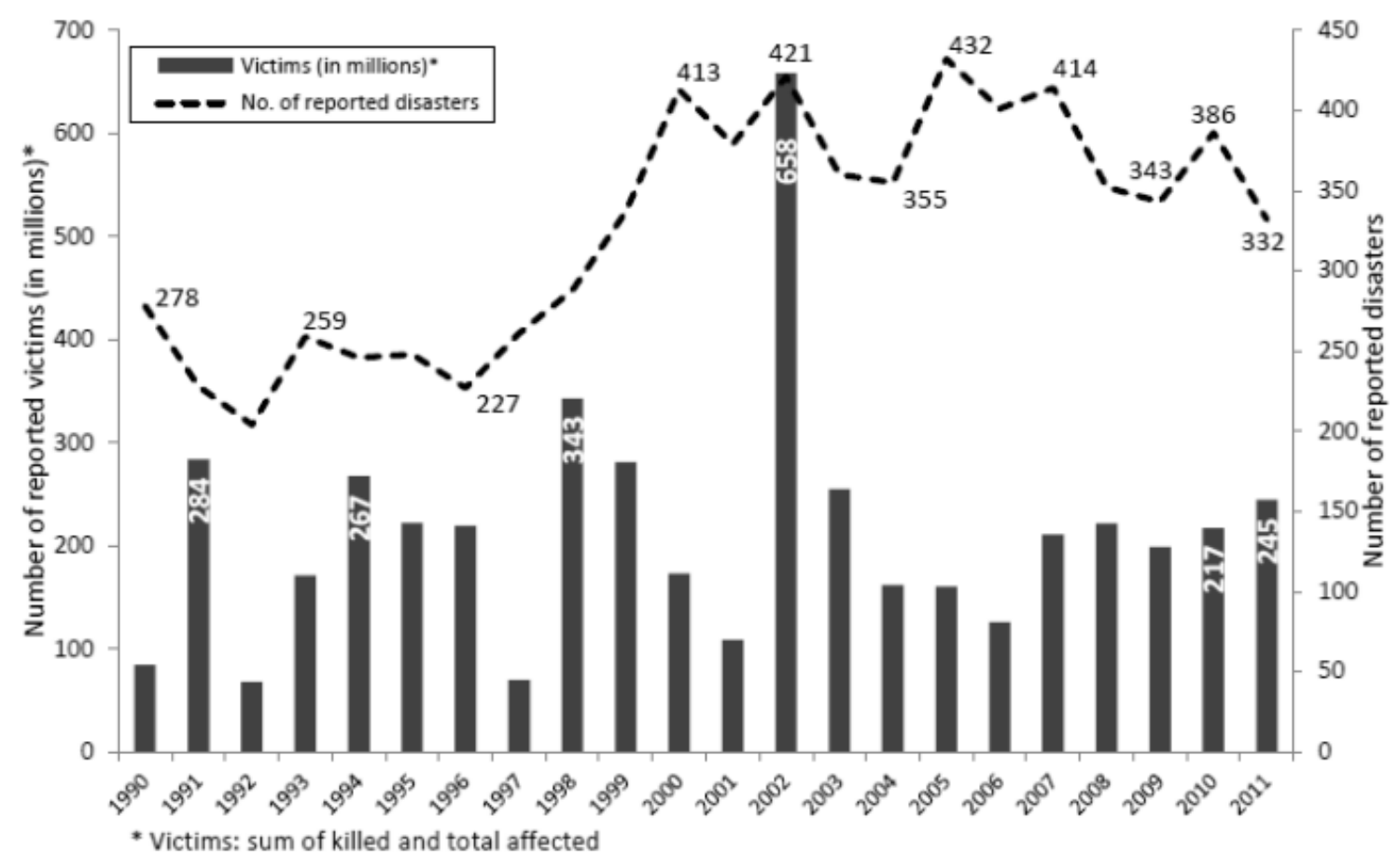

Delivering substance to the living in the immediate relief response stage is only the beginning of the situation. The safety, protection and health of the living; the rehabilitation and reconstruction of the aftermath and sustaining the security, continuity of the reconstruction and development of the region means that there are a number of different logistical phases involved in humanitarian logistics.

\section{Current supply chain theory: comparison of commercial, military and humanitarian}

The literature frequently highlights that commonalities exist between humanitarian and military supply chain, such as: both have dynamic and uncertain demand patterns, face difficulties due to degradation of the local physical infrastructure as well as to the absence of certain governmental functions, attend injured and traumatised victims and are in constant observation of the media (Balcik et al., 2010; Tatham and Kovács, 2010).

Given the fundamental differences between commercial supply chains and humanitarian supply chains (Beamon, 2004; Kovács and Spens, 2007; Oloruntoba and Gray, 2006; Thomas and Kopczak, 2005; Van Wassenhove, 2006) and the similarities between humanitarian supply chains and military supply chains (Oloruntoba and Gray, 2006; Pettit and Beresford, 2005; Rietjens et al., 2007; Skoglund and Hertz, 2007; Tatham, 2006; Tysseland, 2007), a number of issues as presented in Table 1 have materialised.

Kovács and Tatham (2009) demonstrated that both humanitarian and military supply chains in contrast to commercial supply chains have to plan to respond for what they view as inevitable events such as natural or complex disasters. In comparison, commercial supply chains find difficulty in dealing with disruption and plan to improve resilience to overcome disruptions as quickly as possible (Christopher and Peck, 2004). Similarly, humanitarian organisations focus on delivering aid to people affected by disasters; whilst military organisations need to prepare for (and engage in) warfare or peacekeeping missions (Kovács and Tatham, 2009). Both cases require the speedy mobilisation of resources and capabilities from a preparation phase to a recovery state as a response to a disruption.

Oloruntoba and Gray (2006) describe the humanitarian domain as diverse and competitive, where agencies compete to attain support from donor groups for specific operations and principles. In tandem with the increasing number and severity of international disasters (Vos et al., 2010), this creates a security conscious, complex aid environment in which it is necessary to focus on core competencies to ensure long-term operational success through 
fulfilling defined humanitarian briefs. Partnerships constitute a method through which organisations operating in volatile or highly specialised fields tend to share their complimentary competencies to ensure optimal outcomes. Arguably, concentration in this manner ensures survival or optimal development.

Table 1. Comparison of issues affecting commercial, military and humanitarian supply chains

\begin{tabular}{|c|c|c|c|c|}
\hline Issue & $\begin{array}{l}\text { Commercial } \\
\text { SCM }\end{array}$ & $\begin{array}{l}\text { Military } \\
\text { Logistics }\end{array}$ & $\begin{array}{l}\text { Humanitarian } \\
\text { Logistics }\end{array}$ & Authors \\
\hline $\begin{array}{l}\text { Funding of Supply } \\
\text { Chain }\end{array}$ & Sophisticated & Sophisticated & Problematic & $\begin{array}{c}\text { Apte (2009); Jahre et al. (2009); Kovács } \\
\text { and Spens (2007); Littieri et al. (2009); } \\
\text { Natarajarathinam et al. (2009); Overstreet } \\
\text { et al. (2011); Shaluf (2007); Tatham } \\
\text { (2012); Tatham and Pettit (2010); Van } \\
\text { Wassenhove., (2006) }\end{array}$ \\
\hline $\begin{array}{l}\text { Preparedness } \\
\text { in Supply Chain }\end{array}$ & Not an issue & Not an issue & Major issue & $\begin{array}{l}\text { Eriksson (2009); McLachlin et al. (2009); } \\
\text { Perry (2007); Rutner et al. (2012) }\end{array}$ \\
\hline $\begin{array}{l}\text { Cooperation } \\
\text { amongst Supply } \\
\text { Chain actors }\end{array}$ & Well defined & $\begin{array}{c}\text { Amongst military and allies } \\
- \text { Well defined } \\
\text { Civil-military cooperation - } \\
\text { major issue }\end{array}$ & $\begin{array}{c}\text { Amongst NGO's / IO's } \\
\text { - improving } \\
\text { Civil-military } \\
\text { cooperation - major } \\
\text { issue }\end{array}$ & $\begin{array}{c}\text { Akhtar et al. (2012); Carroll and Neu } \\
\text { (2009); Heaslip et al. (2012); Jahre } \\
\text { and Jensen (2010); Maon et al. (2009); } \\
\text { McLachin and Larson (2011); Rietjens } \\
\text { et al. (2007); Shultz and Blecken (2010); } \\
\text { Stewart et al. (2009) }\end{array}$ \\
\hline $\begin{array}{l}\text { Phases in Supply } \\
\text { Chain }\end{array}$ & Well defined & Well defined & Evolving & $\begin{array}{l}\text { Chang et al. (2010); Kovács and Tatham } \\
\text { (2009); Richey et al. (2007, 2010) }\end{array}$ \\
\hline $\begin{array}{l}\text { Information Sharing } \\
\text { throughout Supply } \\
\text { Chain }\end{array}$ & Advanced & Advanced & Limited & $\begin{array}{c}\text { Pourezzat et al. (2010); Walker and } \\
\text { Harland (2008) }\end{array}$ \\
\hline
\end{tabular}

The above have been formalised into frameworks depicting the different types of partnerships in supply chains ranging from arm's length, cooperative, coordinated, collaborative, joint ventures and vertical integration (Kampstra et al., 2006; Kottila and Ronni, 2008; Skjoett-Larsen et al., 2003). Within such scales of relationships, there are no definitive interpretations of the intervening states which not only overlap but are also often differently described in the literature. The nature of such partnerships will blur and alter over time thus it is appreciated that within any given relationship, elements may be characterised by a different approach - in other words some may be transactional, whilst others cooperative. For example, Whipple and Russell (2007) suggest that collaboration can best be analysed in terms of transaction management, event management and process management.

As identified by Moan et al. (2009) and Wild and Zhou (2011), traditional commercial supply chain frameworks may not be suitable as frameworks to understand the systematic processes and relationships within humanitarian supply chains.

\section{Military involvement in humanitarian logistics}

According to Jahre et al. (2009) humanitarian supply chains are seen as temporary entities in which activities can be completed in an ad hoc manner. Their resources, personnel, procedures and processes are often the results of fast and urgent planning (Jahre et al., 2009). Military involvement in humanitarian supply chains possesses many of the capabilities that address these shortfalls. The nature of humanitarian aid delivery, peace-making and keeping has become more complex over the past few decades, which have reflected on the complexities and nature of military involvement in assisting the provisioning and support of logistical aid. The request for military responses to a natural disaster can depend upon the scale and urgency of the disaster, the level of preparedness, the prior established relationships between the affected host and assisting nation; politics and policy of the host nation; geographical proximity and whether the assisting country has the availability of military assets to give for assistance (Heaslip et al., 2012).

There is often a lack of effective coordination mechanisms to promote linkages and collaboration between diverse supply chain participants in humanitarian supply chains. The need for better coordination according to Whiting and Ayala-Ostrom (2009) is particularly compelling due to the logistics expenditure consumes up to $40 \%$ of the total humanitarian aid budgets. Rietjens et al. (2007) argue conflicting objectives between humanitarian organisations and military often leads to resource wastage as relief agencies and military units undertake similar operations. This duplication is not only prevalent between NGOs and military but also between different NGOs. To ensure optimal resource usage, they argue that the military involvements should adopt a subordinate role to the 
humanitarian lead agency. Nevertheless they acknowledge that the humanitarian agency needs to be present to provide appropriate guidance, and this is often not possible as the military forces are the units first to reach the disaster area with air support and relief provisioning (Rietjens et al., 2007).

\section{Practical implications and examples of military involvement}

In 1999, around a million refugees fled or were expelled from Kosovo the UNHCR was, in common with most Western decision makers and commentators, unprepared for the scale and speed with which the crisis deteriorated (Morris, 1999). As the situation worsened the then High Commissioner (Mrs Sadako Ogata) invited NATO forces to construct a series of refugee camps with the result that five were built in 96 hours to house over 60,000 people who were stranded on the Kosovo-Macedonia border. Whilst her decision to invite NATO to enter the 'humanitarian space' was criticised by some NGOs at the time, the reality is that these camps were built in record time (Porter, 2000) and, arguably, this could only have been achieved by the military. In the context of this paper, this example provides an excellent demonstration of the core logistic capability of many armed forces, which have the appropriate people, processes and technology to be able to move swiftly and effectively to achieve such tasks in support of the UN and wider humanitarian community.

Barber (2011) describes some of the military logistics contribution to the Haitian earthquake disaster in 2010. The helicopter carrier USS Bataan and three large dock-landing ships as well as two US survey/salvage vessels created a sea base for the rescue efforts. The French Navy provided the Navy ship, the Francis Garnier, and an amphibious transporter, the Siroco. The US hospital ship, USNS Comfort, was extensively used for emergency operations of over 600 casualties of the earthquake. The US Navy contribution to the Haiti disaster was 17 ships, 48 helicopters, and 12 fixed-wing aircraft together with 10,000 sailors and Marines. The US Navy delivered 32,400 gallons of water and 532,440 bottles of water, over 100,000 meals and massive medical supplies after 5 days. A similar armada provided a floating hospital and recreation base around East Timor during 1999-2000.

The donation and delivery of hospital supplies during a storm in Haiti, the reconstruction of the power grid in Najaf, the distribution of blankets to orphans in Afghanistan, and the construction of a new maternity ward at a Basra hospital all represent humanitarian and reconstruction work that is conducted by the international community (Devenney, 2004; O'Neill, 2004; Richards, 2005). Projects such as these are easily associated with the work of United Nations agencies, government development agencies like USAID, and NGOs such as the International Committee of the Red Cross (ICRC), CARE, Médecins Sans Frontières (MSF), and Oxfam. However, these projects, and hundreds of others like them, were, and continue to be, delivered by American, Australian, British, Canadian, Dutch, and many other militaries involved in humanitarian operations.

\section{Research design}

The approach in this paper is phenomenological; that is, it is driven by particular problems in the coordination of humanitarian relief operations that existing theoretical frameworks have only studied to a limited degree. Such an approach has several implications. It is reasonable to treat this as a context of discovery, in which it is important to collect a rich information base for exploration (Glaser and Strauss, 1967). The study is interpretative in nature and based on a combination of semi-structured interviews, as well as UN, Military and NGO documentation on coordination, including several evaluation reports. Since the purpose is to investigate some of the critical questions in humanitarian aid and tie these to existing theory on coordination, the goal of the paper is to create a model (see Figure 4) rather than test theories.

In this paper, validity is ensured by combining the results of desk research with the data received from semistructured interviews, internal documentation and presentations obtained and published information. The interviews took place over a 14-month period from February 2009 to April 2010. The interviewees generally held the following positions: initiator or head of the cooperation initiative, procurement officer, logistics officer, United Nations (UN) liaison officers, Office for the Coordination of Humanitarian Affairs (OCHA) cluster staff, and (potential) customers/participants/ users of the cooperation and were from different NGOs, International Non-Government Organisation's (INGOs) and the Australian Defence Forces (ADF), United Kingdom Ministry of Defence (UK MOD) and the Irish Defence Forces (IDF). Table 2 provides detail in terms of the number and type of people interviewed during the course of the research. 
Table 2. Personnel interviewed

\begin{tabular}{lcc}
\hline Organisation & Number of People Interviewed & Functions Interviewed \\
\hline \hline $\begin{array}{l}\text { Irish Defence Forces } \\
\text { Canadian Military }\end{array}$ & 6 & $\begin{array}{c}\text { Senior Management } \\
\text { Logistics and Operations staff }\end{array}$ \\
$\begin{array}{l}\text { US Military } \\
\text { World Vision }\end{array}$ & 2 & Logistics Officers \\
UNHCR & 3 & Logistics and Operations Officers \\
Oxfam & 3 & Senior management \\
Logistics and Operations staff
\end{tabular}

In terms of data management, digital folders were created for archiving system for each case study. A chain of evidence was established by documenting data sources in the case study reports and analysis. Data analysis involved a process of data reduction and reconstruction. In the data reduction phase, collected data were subjected to a coding process that allowed them to be disaggregated so that key themes in the data became apparent. The data were analysed in a two-stage process that was heavily inductive (Lofland and Lofland, 1995). During the first stage, transcribed interview notes were examined for instances during which issues pertaining to the collaborative nature of the project (working together) were noted. Initial labels were then attached to these data elements that in some way pertained to collaboration, either between the military and the agencies or the agencies themselves. The second stage of coding was an analysis of the initial codes. During this focused coding (Lofland and Lofland, 1995), the initial codes were sorted into similar groups, to which labels were then attached. Subsequently, the analysis and synthesis of results was carried out through feedback and discussion with associated humanitarian aid logistics stakeholders (NGOs and military forces).

The study has several important limitations. Since the entire research cannot be presented, in some cases because of security reasons, the paper offers only a reduced set of quotes and descriptions. Civil-military logistical coordination is changing rapidly in both natural and complex emergencies disasters. In this sense, the concept is fluid, and it is difficult to do it justice in any one description. Nonetheless, the basic problems that arise in coordination and the greater theme of coordination in humanitarian logistics continues to remain. The following section details the phases in humanitarian relief and the impact on logistical challenges.

\section{Phases in humanitarian relief}

Within the literature (Heaslip et al., 2012; Jahre and Jensen, 2010; Kovács and Spens, 2007; Listou, 2008), there is agreement that different operations can be distinguished in the times before a disaster strikes (the preparation phase), instantly after a disaster (the immediate response phase) and in the aftermath of a natural disaster (the reconstruction phase). Not surprisingly, different logistical requirements, resources and skills are needed for the three distinct phases of disaster relief.

Haas et al. (1977) illustrated the cycle of activity in a recovery model. This identifies the overlaps that occur between each of the phases of the full emergency relief cycle (Figure 2). Safran (2003) usefully emphasises the cyclical nature of disaster relief (see Figure 3). Many humanitarian organisations adopt the circular, learning loop model that links these phases to each other, borrowing from Safran's (2003) disaster relief cycle.

Nevertheless in this cyclical model the overlap between the different phases is not acknowledged. This is a major failing of the cyclical model which are difficult to demonstrate the transition areas and necessary overlaps between the phases and diagrammatically impossible to demonstrate the overlap of non-sequential phases with earlier phases, for example the restoration and rebuilding stage or the restoration and transition to host government organisations. 
Figure 2. A suggested model of emergency recovery (Source: Haas et al., 1977)

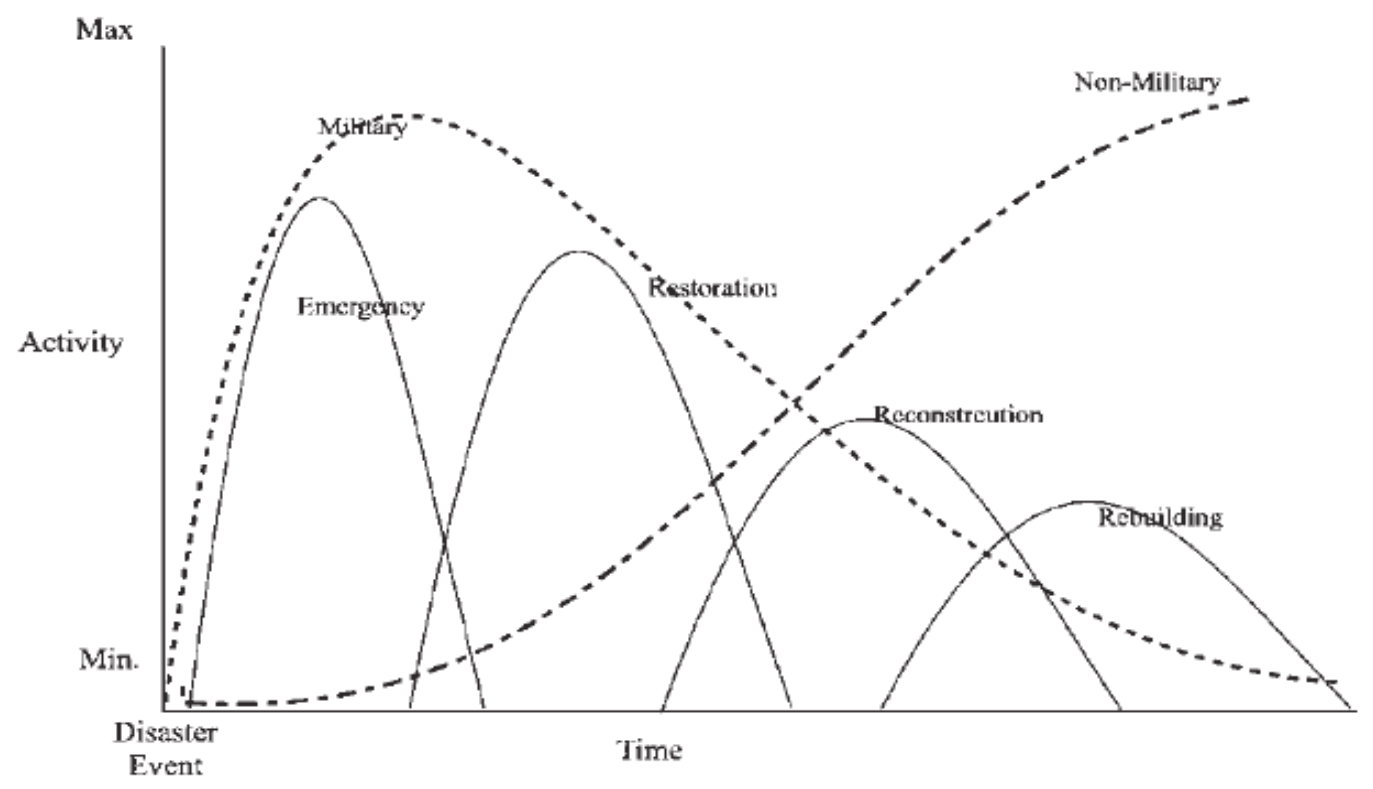

Figure 3. Safran's circular model (Source: Safran, 2003)

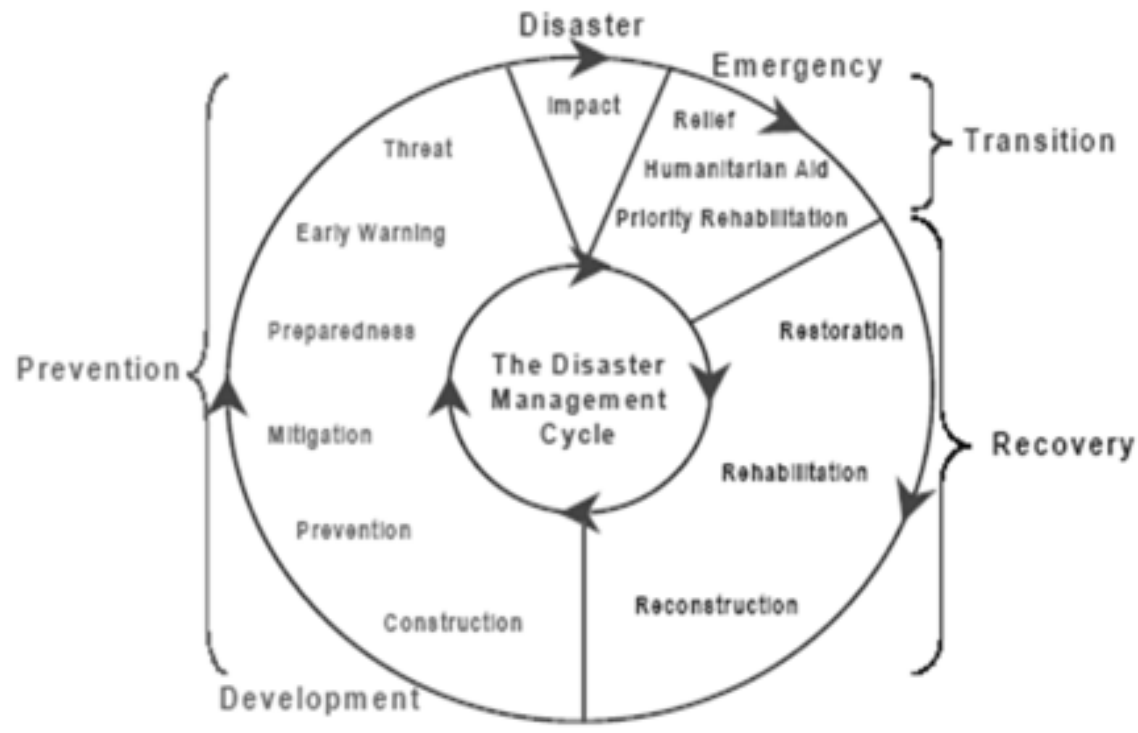

Thus, the recovery phases of a disaster needs to link to a new prevention phase to mitigate the effects of future potential disasters. Kovács and Spens (2007) argue different operations can be distinguished in the times before a disaster strikes (the preparation phase), instantly after a disaster (the immediate response phase) and in the aftermath of a natural disaster (the reconstruction phase). A similar phased approach to the management of such humanitarian disasters is offered by Long (1997). 
When each phase overlaps significantly the important requirement is sustainability and continuity of functions and activities so that the appropriate flows of goods and services as well as information and financial flows are not disrupted due to the rotation of logistical staff or organisations involved in different phases.

The unpredictable nature of the majority of disasters calls for quick deployment and constant reconfiguration of staff and resources at the disaster site (Kovács and Tatham, 2009). Emergencies are subject not only to the dynamics of knowledge but also distance, criticality and time pressure during both the planning and response phases (Heaslip et al., 2012). Planning relies on access to large volumes of information, especially up-to-date logistics-related information. Throughout a crisis, information is distributed unequally amongst humanitarian organisations and between the military and humanitarian organisations. As each humanitarian organisation occupies a specific node in the information chain, access to sources of information varies significantly between organisations.

More importantly, OCHA, the UN logistic clusters, and partnerships amongst global logistics companies have addressed the issue of continuous evolution and flow of a vast category of logistics-related information across geographies and actors. Added to these complexities is the dual cycle model (Moan et al., 2009) which is based on the premise that the phases in humanitarian aid often overlap and are interrelated. The dual cycle model shows the relationships between the prevention and planning cycles of preparedness and mitigation and the different relationships necessary for logistical support in the reaction and recovery cycles of emergency response and the restoration and reconstruction phases.

\section{Proposed model}

Given all these confounding variables, it is not surprising that many disaster management models have appeared in the literature. Asghar et al. (2008) separates the various models into four categories, namely, logistical, integrated, causal, and 'other' models. For the purposes of our research, we concentrate on the logistical models.

The traditional logistical models were sequential in nature. Kimberley (2003) uses the four traditional phases of mitigation, preparedness, response, and recovery and emphasises the response phase as the biggest phase that will be more effective with appropriate mitigation and preparedness. It was limited to hospital preparedness but the emphasis on preparedness and the longevity of response and recovery is easily adaptive to any support organisation.

Military organisations must be able to operate in both conflict and disaster situations and have to adapt to conditions prevailing at any given moment. Thus, their stance will vary depending on the situation on the ground. This in turn will have an impact on the logistics response. One of the identifiable trends is the increasing need for agility (adaptability) of military logistical support, with less emphasis on buffer stock and more on manoeuvrability (Heaslip et al., 2012; Jahre and Jensen, 2010). Effectively, this means that agility and scale need to be separated. Within this structured approach to rebuilding society, there is an important role for the provision of humanitarian aid. In the context of Kimberley's (2003) four phases of disaster management - preparedness, response, and recovery - logistics has an important role to play.

Very early works such as the Asian Disaster Preparedness Centre training books (ADPC, 2000) and the South African Provincial Affairs and Constitutional Development Disaster Management programs (DPLG-2, 1998) reflected the overlap or paralleling of these phases. The integrated development plans of the South African Republic reflect this paralleling as well as the complexities of integrated support across many provinces (IDP, 2011). The importance of integrating the preparedness stages with the immediate relief and redevelopment stages is not demonstrated by the minimal transition stages as shown in Figure 4.

In our model, we have adopted a sequential process which includes three phases: phase 1, disaster relief; phase 2, rebuild and reconstruction; and finally phase 3; host nation finalisation of rebuild. As any situation develops through the three phases, there will be a shift in the balance of effort being provided by the various organisations. 
Figure 4. Sequential logistical model emphasising transitions of humanitarian logistics

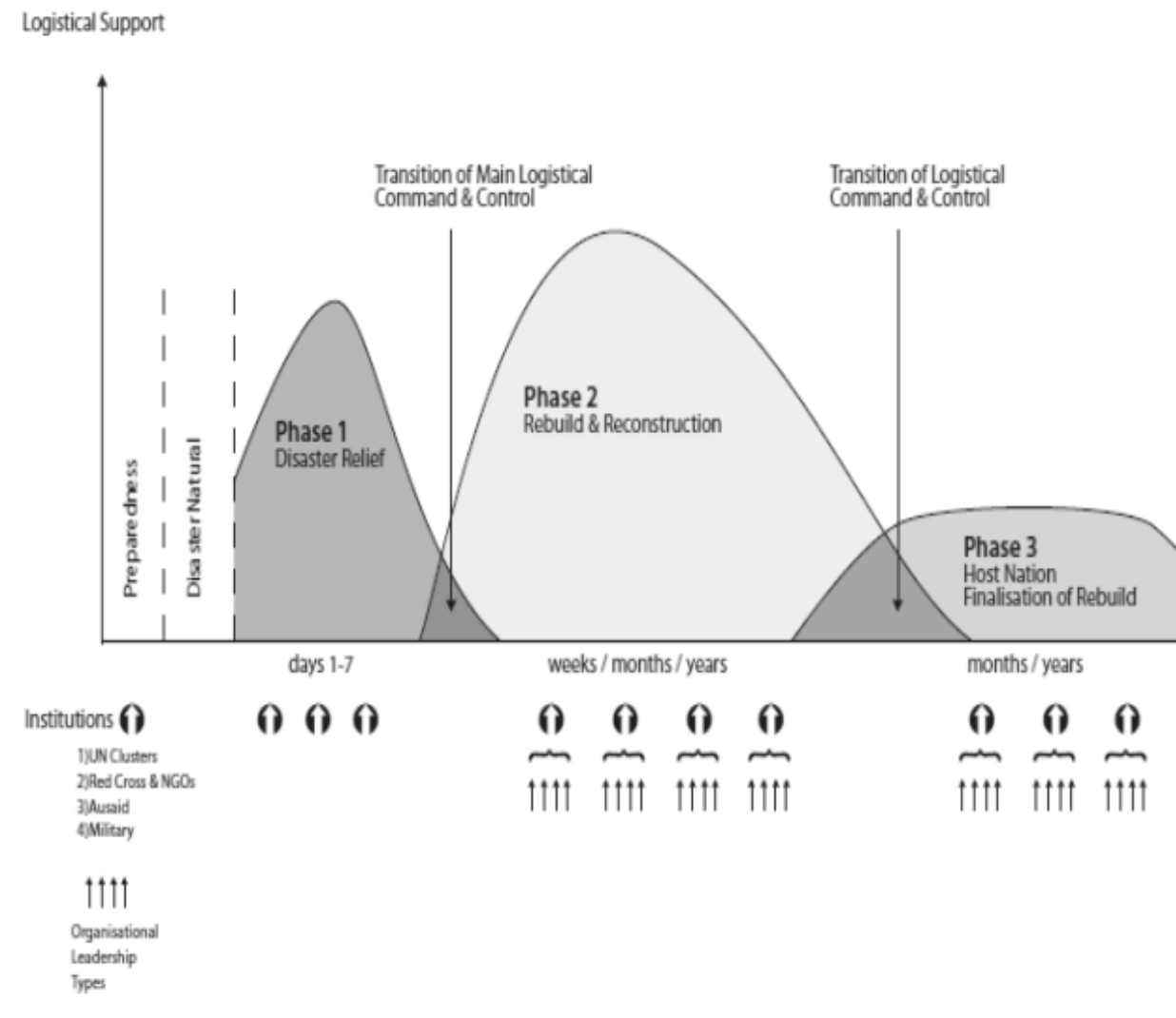

\section{Phases of the model}

In phase 1, in response to a natural disaster the military deploy with their logistics capacity, for example, trucks, air lift capacity, fuel, and personnel. This phase sees the greatest level of effort provided by the military. Examples of this action occurred in New Orleans, Haiti and most recently in the Philippines. Military transport was utilised to evacuate victims and to transport aid workers and aid into the area. They respond quickly with supplies located within country or from allies' stores located in the region (Heaslip et al., 2012). Military organisations have the robustness to operate in harsh field conditions and are capable of $12 \mathrm{~h}$ response operations on a large scale (Kovács and Tatham, 2009). The structured command and control systems coupled with appropriate asset capabilities that sustain the military personnel are not found in most NGOs or INGOs.

As time progresses, the model moves to phase 2 where the level of input from the military will gradually reduce as other humanitarian and development organisations gear up and increase their level of input. Equally, the level of involvement of the military and civilian organisations is likely to be affected by the general level of development in the country, the level of resources that they are able to commit to a particular situation and the level of infrastructure deterioration. More developed countries are likely to be able to rely more heavily on non-military organisations, whereas less developed countries tend to depend proportionately more on military assistance during a humanitarian disaster.

In phase 3, the reconstruction activities aim to bring the disaster under control such that the affected population is capable of resuming responsibility, all systems are returned to a normal or better state, and communities are returned to their pre-disaster conditions (including livelihood, homes and infrastructure) (Campbell and Jones, 2011). This phase sees the shift in focus from speed to cost reduction, with reconstruction's objective being 'costs saved means more lives helped' (Cozzolino et al., 2012: 21). During the post-disaster reconstruction and rehabilitation phase of a disaster response, logistic needs shift to support rehabilitation and long-term recovery. Throughout this 
phase, the focus will be on community resilience and environmental issues. Throughout this phase, the military gradually decrease their activities and plan for exiting the disaster site (Cross, 2011).

The final phase of host nation transfer is included in this phase. With further development, this diagram will show the transition of logistical support from the host nation will extend fully along the spectrum beginning in the disaster relief phase and gaining involvement and influence over time. The current logistical models only consider the physical infrastructure, physical product flows and ignore the importance of governance, cultural processes and the host nation's governmental involvement. The complexities of the host nation regardless of whether it is a complex conflict such as Afghanistan or a natural disaster like the Pakistan massive floods or the Indonesian tsunami in 2004 the intricacies of the host nation must be (and in practice is) taken into account even before the initial entry.

\section{Transition of logistics command and control}

The supply chain contributions by the various stakeholders responding to disasters often overlap throughout the different phases, because they are executed at the same location, at the same time or because they involve similar tasks. Humanitarian and military organisations need to align their contributions by sharing information and resources, improve planning, specialising in operational tasks and eventually being more collaborative, coordinated and less competitive (Heaslip et al., 2012; Jahre and Jensen, 2010; Kovács and Tatham, 2009). This requires a sharing of command and control structures that affect the logistics response to a disaster.

Collecting and processing information to achieve collaborative planning in highly complex, volatile, and harsh environments has positive and direct influences on the overall decision-making processes within the supply network. The process is typically very dynamic and must be adaptable, this would typically include sharing of information about security, movement of humanitarian convoys and the management of shared resources, for example a port or airport.

The transition of the main logistical command and control functions happens as phase 1 nears an end and phase 2 commences. Clearly, any situation involving military conflict will be intrinsically shaped by the security situation and the ability of NGOs to work, if not with, at least within the confines of military control. Stemming from this will be the balance between the allocation of any military-based logistics effort and that of NGO relief activities. The balance in such cases may well be primarily military in the early stages, but as time progresses and security conditions change, so the transition of the main logistical command and control activities will swing to NGO-based aid provision.

A further consideration will be the balance between a country's indigenous humanitarian aid capability and that of external countries' ability (and will) to participate. The scale of many disasters may well overwhelm internal resources and this will inevitably lead to requests for external intervention, which in turn may well be provided from military capacity.

Similar to the Haas et al. (1977) model our model shows minimal overlap between the different sequential phases as currently viewed by humanitarian logistics models. The proposed model expands the Haas model to show the various organisations and leadership types involved in the logistical flows which now be discussed.

\section{Organisational leadership}

Given that military should complement rather than override humanitarian supply chains we now shift to the need of controlling the coordination and sustainability of them through phases 2 and 3 , as indicated. Although the military would like to control all of the logistics chain, they recognise that a proportion has to be outside their control. Thus, whilst the strategic, operational, and tactical levels are separate, a 'control-at-arms-length' approach may be taken. Decisions taken at the tactical level may have an impact on strategy, an example of strategy affecting the supply of humanitarian aid on the ground being the movement of supplies.

Smith (2010) expands on the 'hard,' 'soft,' and 'smart' power of militaries being the war power, the support to humanitarian aid power and the intelligence superiority power to assist in aid delivery, respectively. This is similar to the categorisation of Wild and Zhou (2011) power in stakeholder relationships, namely, power, legitimacy, and urgency.

The military are the dominant player in humanitarian relief situations of complex emergencies but how they incorporate and transition to NGOs is a delicate and sometimes dangerous call (Heaslip, 2011). The military are often not the dominant player in natural disaster situations with the host nation, such as leading the aftermath and subsequent development from the Japan tsunami, to OCHA and UN agencies taking the lead in most disasters in underdeveloped nations (Barber, 2011).

Consequently, the 'smart power' can lead to a dominant position but once the transitions start to rehabilitation, reconstruction the dominant roles may fall to the host nation, the NGOs or the UN. The preparation stage is where 
the military can take a less dominant role leaving the UN to lead and coordinate. The UN has already taken the lead in establishing clusters and inventory contracting and stockpiling. In a situation where some nations will refuse aid from a particular country (Whybark, 2007) the use of the UN central stockpiles can be used. Management of these inventories are complicated and require sophisticated control of the storage, locations, outgoing demand flows, incoming supply flows, transportation, obsolescence management and security all come at a cost. Military can assist in the preparedness phase by sharing their excess capacity in their warehouses which may be needed in times of war but not in peace time.

\section{Increased cooperation of military logistics support}

There has been a shift in military logistical roles over the last decade to incorporate their involvement in humanitarian logistics. Military involvement in humanitarian supply chains falls under the term, Military Involvement in Operations Other Than War (MOOTW). The parallels are striking between the military logistics and the humanitarian logistics. Weiss and Campbell (1991) discuss the historical context of military involvement in humanitarian aid. They suggest that military responsibility should be used not only for rapid deployment of supplies and provisions but also questions the appropriateness of military involvement. Increasingly, the military has become a key member of immediate disaster relief (Barber, 2011). It has expanded from rapid deployed transportation and logistical requirements and assets and is now involved with the more complex tasks of refugee protection, repatriation, and peacekeeping. Military is also often involved in medical advancements, rehabilitations, and reconstruction of facilities.

The main reasons cited for the increased military involvement are varied. The United Kingdom in their Defence White Paper and Australia in its Strategic Defence Review included humanitarian aid as a military role (Greet, 2008). It is not surprising with the Asia-Pacific being the most natural disaster prone region in the world that the ADF recognised that this area whilst being the most prone, when afflicted its residents are also the most vulnerable to the impacts of disasters (ASPI, 2011). In 2009, it altered its doctrine (Operation Series ADDP, 2009) to include in particular details on logistic support requirements. It acknowledges that military and international humanitarian organisations will be working 'side-by-side' with many overlapping and co-ordinated logistical efforts.

Collaboration can take place at different stages along the relief chain (Oloruntoba and Gray, 2006), e.g. during contingency planning, need assessment, appeals, transportation management, or last-mile distribution. Whilst collaboration during an actual disaster (Thomas and Kopczak, 2007), especially at field level, seems to be more common, and has been enhanced through the setup of the UN Joint Logistics Centre (Heaslip, 2008, 2011), there is a specific need for better, continuing collaboration after an operation, in preparation for the next one (Thomas and Kopczak, 2007). Particularly, only limited cooperation is reported or documented during the preparation phase of the disaster relief lifecycle. The continual change and inevitability of military involvement in humanitarian aid is due to the increase in natural disasters and complex emergencies (EM-DAT, 2010). NGOs are training more frequently with military forces and becoming acclimatised to military involvement in humanitarian aid (Tatham and Kovács, 2010).

In the preparation phase military forces excel. Their preparation and training is consistently practiced and updated. They have consistent cash flows, procedures, protocols, doctrine and processes all of which enable setting up of supply chains in harsh environments a well-oiled practice. Coupled with the human resources are the capability assets and superior technologies. Within the preparation phase, the military's ability to train on and develop reliable communications and information systems is superior to the humanitarian community. Communications and information systems are as important for the military in war and conflict situations as it is for humanitarian supply chains (United-Nations, 2007). Significant training and equipment is dedicated to enable both formal and informal communications to be received in harsh situations. The information systems are well suited for global reach and personnel are well trained in its use. Lessons learned from the Indian tsunami in 2006 were severely hampered by excessive and costly reliance on wireless telephones for information. It was viewed that information is a life-saving resource in disaster situations and needs urgent UN attention to coordinate a global reach communication service (United-Nations, 2007).

Military forces are accustomed to operate with limited information and demand uncertainty. They are trained to secure and support provisions based on broad estimates. The capabilities and infrastructure assets owned and operated by military forces are suitable for harsh terrain and green field sites (Long, 1997). Military forces have dedicated air assets specifically designed to transport large quantities of supplies into areas of operation. These planes are highly valuable in the early stages of disaster relief (Operation Series ADDP, 2009). 
Nevertheless military operations cost public money and military contributions are only conducted at the will of the national government. The accountability and numerous processes, doctrinal conditions and procedures can significantly slow the military involvement (Weeks, 2007). Pettit and Beresford (2005) argue that the use of military in humanitarian aid operations can carry unwanted perceptions and can compromise the neutrality of NGOs working in the disaster relief areas. Nevertheless the military have a wide range of logistic capabilities which are self sustaining and have rapid deployment capabilities as invaluable stop gap measures until the civilian capabilities can take of the relief supply chains. Pettit and Beresford see some vital needs for military in roles such as: the protection of NGO personnel, aid supply, distribution hubs, enforcing peace and restoring order. Military organisations can also provide assistance with refugees and displaced persons. They see the lines between humanitarian and military operations blending although the military should still be employed very much in their original role, as a security and combat force.

\section{Implications for supply chain practice}

There is an inherent difference between asset-heavy mass production type not-for-profit supply chains, and their asset-light counterparts, or in a view that is similar to Skjoett-Larsen et al.'s (2003) governance models in supply chain collaboration, there is an inherent difference between vertical integration fitting the internal-resource focused military supply chain and supply chain integration fitting the humanitarian supply chain with its focus on internalising resources from its supply network (Kovács and Tatham, 2009). For commercial supply chains, lessons can be learned by examining the management of resources that are internal and external to an organisation specifically in disruptive events.

The resource configuration of an organisation (be it commercial, military or humanitarian) impacts largely on the capabilities it needs. In the military supply chain, an asset-heavy organisation focusing on training activities, the capabilities to manage disruptions rely on the skills of employees (human capital resources) combined with rigid rules and procedures, and supported by the ready availability of any necessary equipment (Kovács and Tatham, 2009). A characteristic of military supply chains is its capability to stand alone, drawing on purely organisationinternal resources that are constantly developed further. On the other hand, the humanitarian supply chain relies on organisational external resources and thus needs to focus on the capability to manage relationships with suppliers, donors, as well as other humanitarian organisations (aid agencies and NGOs), governments, logistics service providers, and yes, the military, i.e. the entire humanitarian aid supply network.

\section{CONCLUSION}

Civil-military logistical cooperation truly is evolving, and the process has gained momentum in recent years. Simply providing security will not be enough for military forces in an environment where perceptions and ideas are centres of gravity in the conflict. Evolution will continue as more lessons learned are incorporated from more theatres, and ideally projects can find a less controversial niche. Theatres of operation in complex fragile states are dynamic, changing environments, and a universally applicable model to civil-military logistical cooperation is therefore difficult if not impossible to obtain. Civil-military logistical cooperation will therefore remain in a state of evolution.

This paper demonstrates that there is a need for those involved in humanitarian logistics to reflect on the lessons learned from civil-military humanitarian assistance. In particular, the greatest impact of military involvement is in the initial crucial life sustaining days immediately after natural disasters. In contrast, in manmade complex emergencies, military assistance to the logistical provision of aid is more beneficial when widespread military expertise is provided. Current logistics models are not showing the transition overlaps either between the various sequential phases or the overlapping stages across the phases. The proposed model expands this traditional model to show the various organisations and leadership types involved in the logistical flows. It demonstrates the added complexities associated by integrated logistics requirements in disaster management across all phases and shows the interdependencies of the military and humanitarian agencies.

\section{Endnote}

1 Complex emergencies are disasters that involve both man-made and natural events such as the 2011 Japanese Tsunami followed by the damage to the nuclear plant; or natural disasters complicated by war / fighting. 
ADPC (2000). ENSO 'Impact and Potential Forecast Applications in Indonesia. Extreme Climate Events Programme'. Asian Disaster Preparedness Centre, Bangkok, Thailand.

Akhtar, P., Marr, N.E. and Garnevska, E.V. (2012). 'Coordination in humanitarian relief chains: Chain coordinators'. Journal of Humanitarian Logistics and Supply Chain Management, 2: 1, 85-103.

Apte, A.U. (2009). 'Humanitarian logistics: A new field of research and action. Foundations and Trends in Technology'. Information and Operations Management, 3: 1, 1-99.

Asghar, S., Alahakoon, D. and Churilov, L. (2008). 'Categorization of disaster decision support needs for the development of an integrated model for DMDSS'. International Journal of Information Technology \& Decision Making, 7: 1, 115-145.

ASPI (2011). 'More than good deeds: Disaster risk management and Australian, Japanese and US defence forces'. Australian Strategic Police Institute, Special Report, 43.

Balcik, B., Beamon, B.M., Krejci, C.C., Muramatsu, K.M. and Ramirez, M. (2010). 'Coordination in humanitarian relief chains: Practices, challenges and opportunities'. International Journal of Production Economics, 126: 1, 22-34.

Barber, E. (2011). 'Military involvement in humanitarian supply chains', in G. Kovács and K. Spens (eds), Relief Supply Chain Management for Disasters: Humanitarian Aid and Emergency Logistics, US: IGI Global.

Barney, J.B. (1991). 'Firm resources and sustained competitive advantage'. Journal of Management, 17: 1, 99-120.

Beamon, B.M. (2004). 'Humanitarian relief chains: Issues and challenges', in Proceedings of 34th International Conference on Computers and Industrial Engineering, San Francisco, CA, USA, November 14-16.

Campbell, A.M. and Jones, P.C. (2011). 'Prepositioning supplies in preparation for disasters'. European Journal of Operational Research, 209, 156-165.

Carroll, A. and Neu, J. (2009). 'Volatility, unpredictability and asymmetry: An organising framework for humanitarian logistics operations?'. Management Research News, 32: 11, 1024-1037.

Chang, Y., Wilkinson, S., Seville, E. and Potangaroa, R. (2010). 'Resourcing for a resilient post-disaster reconstruction environment'. International
Journal of Disaster Resilience in the Built Environment, 1: 1, 65-83.

Christopher, M. and Peck, H. (2004). 'Building the resilient supply chain'. International Journal of Logistics Management, 15: 2, 1-13.

Cozzolino, A., Rossi, S. and Conforti, A. (2012). 'Agile and lean principles in the humanitarian supply chain: The case of the United Nations World Food Programme'. Journal of Humanitarian Logistics and Supply Chain Management, 2: 1, 16-33.

Cross, T.C. (2011). 'Disaster agencies and military forces - not such strange bedfellows after all!', in M.G. Christopher and P.H. Tatham (eds), Transforming Humanitarian Logistics - The Journey To Supply Network Management, London: Kogan Page.

Devenney, D. (2004). Civilian and Military Cooperation (CIMIC) Projects make a Difference in Port-auPrince. http://www.army.forces.gc.ca/lfaa_hq/ news_desk/cimic.htm [Accessed 25 November 2011].

DOD [Department Of Defence] (2007). Joint Operations For The 21st Century. http://www.Defence.Gov.Au/ Publications/Fjoc.Pdf [Accessed 15 November 2010].

DPLG-2 (1998). Green paper on disaster management. www.Local.Gov.Za/Dcd/Policydocs/Gpdm2-3.Html

EM-DAT (2010). http://www.emdat.be/sites/default/ files/Trends/natural/world_1900_2009/1e.pdf [Accessed 15 November 2010].

Eriksson, E. (2009). 'Knowledge transfer between preparedness and emergency response: A case study'. Disaster Prevention and Management, 18: 2, 162-169.

Glaser, B.G. and Strauss, A.L. (1967). The Discovery of Grounded Theory, NY: Aldine De Gruyter.

Greet, N. (2008). 'ADF experience on humanitarian operations: A new idea?'. Security Challenges, 4, 45-61.

Haas, J.E., Kates, R.W. and Bowden, M. (1977). Reconstruction Following Disaster, MIT Press: Cambridge.

Heaslip, G. (2008). 'Case study: Humanitarian aid supply chains', in J. Mangan, C. Lalwani and T. Butcher (eds), Global Logistics and Supply Chain Management, New Jersey and Chichester: Wiley.

Heaslip, G., Sharif, A.M. and Althonayan, A. (2012). 'Employing a systems-based perspective to the identification of inter-relationships within humanitarian logistics'. International Journal of Production Economics, 139: 2, 377-392. 
Heaslip, G. (2011). 'Challenges of civil military cooperation/coordination in humanitarian relief', in G. Kovács and K. Spens (eds), Relief Supply Chain Management for Disasters: Humanitarian Aid and Emergency Logistics, US: IGI Global.

IDP (2011). http://Cgta.Mpg.Gov.Za/Idp/ Gertsibande2011-12/Dipaleseng2011-2012.Pdf

Jahre, M. and Jensen, L.M. (2010). 'Coordination in humanitarian logistics through clusters'. International Journal of Physical Distribution \& Logistics Management, 40: 8-9, 657-674.

Jahre, M., Jensen, L.M. and Listou, T. (2009). 'Theory development in humanitarian logistics: A framework and three cases'. Management Research News, 32, 1008-1023.

Kampstra, R.P., Ashayeri, J. and Gattorna, J. (2006). 'Realities of supply chain collaboration'. International Journal of Logistics Management, 17: 3, 312-330.

Kimberley, A. (2003). 'Disaster preparedness in Virginia Hospital Centre - Arlington after Sept 11, 2001'. Disaster Management And Response, 1: 3, 80-86.

Kottila, M.R. and Ronni, P. (2008). 'Collaboration and trust in two organic food chains'. British Food Journal, 110: 4-5, 376-394.

Kovács, G. and Spens, K.M. (2007). 'Humanitarian logistics in disaster relief operations'. International Journal of Physical Distribution \& Logistics Management, 36: 2, 99-114.

Kovács, G. and Tatham, P.H. (2009). 'Responding to disruptions in the supply network - from dormant to action'. Journal of Business Logistics, 30: 2, 215-229.

Larson, P.D. and Halldórsson, A. (2004). 'Logistics versus supply chain management: An international survey'. International Journal of Logistics: Research and Applications, 7: 1, 17-31.

Larson, P.D., Poist, R.F. and Halldórsson, A. (2007). 'Perspectives on logistics vs. SCM: A survey of SCM professionals'. Journal of Business Logistics, 28: 1, 1-24.

Lofland, J. and Lofland, L. (1995). Analyzing social settings, Belmont, CA: Wadsworth.

Long, D. (1997). 'Logistics for disaster relief: Engineering on the run'. IIE Solutions, 29, 26-29.

Listou, T. (2008). 'Postponement and speculation in non-commercial supply chains'. Supply Chain Forum: An International Journal, 9, 56-65.

Littieri, E., Masella, C. and Radaelli, G. (2009). 'Disaster management: Findings from a systematic review'. Disaster Prevention and Management, 18: 2, 117-136.

McLachlin, R. and Larson, P.D. (2011).'Building humanitarian supply chain relationships: Lessons from leading practitioners'. Journal of Humanitarian Logistics and Supply Chain Management, 1: 1, 3249.

McLachlin, R., Larson, P.D. and Khan, S. (2009). 'Notfor-profit supply chains in interrupted environments: The case of a faith based humanitarian relief organisation'. Management Research News, 32: 11, 1050-1064.

Moan, F., Lindgreen, A. and Vanhamme, J. (2009). 'Developing supply chains in disaster reilef operations through cross-sector socially oriented collaborations: A theoretical model'. Supply Chain Management: An International Journal, 14: 2, 149164.

Morris, N. (1999). 'UNHCR and Kosovo: A personal view from within UNHCR'. Forced Migration Review, August, 14-17.

Natarajarathinam, M., Capar, I. and Narayanan, A. (2009). 'Managing supply chains in times of crisis: A review of literature and insights'. International Journal of Physical Distribution \& Logistics Management, 39: 7, 535-573.

NATO (1997). Logistics Handbook, 3rd Ed. http://Www. Nato.Int/Docu/Logi-En/Logist97.Htm [Accessed 25 October 2010].

NATO (2006). North Atlantic Treaty Organisation. Pakistan Earthquake Relief Operation. http://Www. Nato.Int/Issues/Pakistan_Earthquake/Index.Html [Accessed 4 November 2010].

OECD (2012). http://dx.doi.org/10.1787/aid-oda-table2012-1-en [Accessed 10 July2012].

O'Neill, M. (2004). Winning Hearts and Minds. http:// www.forces.gc.ca/site/Feature_Story/2004/ jan04/21_f_e.asp [Accessed 25 November 2011].

Oloruntoba, R. and Gray, R. (2006). 'Humanitarian aid: An agile supply chain?' Supply Chain Management - An International Journal, 11: 2, 115-120.

Operation Series ADDP (2009). 3.8 Peace Operations. Australian Army. Second Edition.

Overstreet, R.E., Hall, D., Hanna, J.B. and Kelly Rainer Jr., R. (2011).'Research in humanitarian logistics'. Journal of Humanitarian Logistics and Supply Chain Management, 1: 2, 114-131.

Perry, M. (2007). 'Natural disaster management planning: A study of logistics managers responding to the tsunami'. International Journal of Physical Distribution \& Logistics Management, 37: 5, 409433.

Pettit, S.J. and Beresford, A.K.C. (2005). 'Emergency relief logistics: An evaluation of military, non-military and composite response models'. International Journal of Logistics Research and Applications, 8, 313-331. 
Porter, T. (2000). 'The partiality of humanitarian assistance - Kosovo in comparative perspective'. The Journal of Humanitarian Assistance, Published JUN 17, 2000.

Pourezzat, A.A., Nejati, M. and Mollaee, A. (2010). 'Dataflow model for managing urban disasters: The experience of Bam earthquake'. International Journal of Disaster Resilience in the Built Environment, 1: 1, 84-102.

Rietjens, S.J.H., Voordijk, G. and De Boer, S.J. (2007). 'Coodinating humanitarian operations in peace support missions'. Disaster Prevention And Management An International Journal, 16: 1, 56-69.

Richards, S. (2005). Flipping on the switch for Najaf electricity. http://www.marines.mil/ marinelink/mcn2000.nsf/a d $\quad 9 \begin{array}{cccccc}9 & 3 & 1 & 5 & 6 & 3\end{array}$ 32 a 819185256 c b 600677 a f $3 /$ e4860f69de5af81785256f93001c2382? [Accessed 25 November 2011].

Richey, R.G., Daugherty, P.J. and Roath, A.S. (2007). 'Firm technological readiness and complimentarity: Capabilities impacting logistics service competency and performance'. Journal of Business Logistics, 28: 1, 195.

Richey, R.G., Roath, A.S., Whipple, J.M. and Fawcett, S.E. (2010). 'Exploring a governance theory of supply chain management: Barriers and facilitators to integration'. Journal of Business Logistics, 31: 1, 237-256.

Rutner, S., Aviles, M. and Cox, S. (2012). 'Logistics evolution: A comparison of military and commercial logistics thought'. The International Journal of Logistics Management, 23: 1, 96-118.

Safran, P. (2003). A strategic approach for disaster and emergency assistance. Contribution to the 5th Asian Disaster Reduction Centre International Meeting and the 2nd UN-ISDR Asian Meeting, 15-17 Jan 2003, Kobe, Japan. http://www.adb. org/Documents/Policies/Disaster_Emergency/ disaster_emergency.pdf [Accessed 4 April 2007].

Shaluf, I.M. (2007). 'An overview on the technological disasters'. Disaster Prevention and Management, 16: 3, 380-390.

Shultz, S.F. and Blecken, A. (2010). 'Horizontal cooperation in disaster relief logistics: Benefits and impediments'. International Journal of Physical Distribution \& Logistics Management, 40: 8-9, 636656.

Skjoett-Larsen, T., Thernoe, C. and Andresen, C. (2003). 'Supply chain collaboration: Theortical perspectives and empirical evidence'. International Journal of Physical Distribution \& Logistics Management, 33:
6, 531-549.

Skoglund, P. and Hertz, S. (2007). 'Local sourcing in peacekeeping operations. A case study of Swedish military sourcing', in P. Tatham (ed), CD-ROM, Proceedings of the International Humanitarian Logistics Symposium, UK: Faringdon.

Smith, M. G. (2010). 'Enhancing Australia's civil military capabilities to prevent, prepare for, and respond to conflict disasters overseas'. Royal Australian Navy Sea Power Conference, Sydney.

Stewart, G., Ramesh, K. and Smith, M. (2009). 'Leveraging public-private partnerships to improve community resilience in times of disaster'. International Journal of Physical Distribution \& Logistics Management, 39: 5, 343-364.

Tatham, P.H. (2012). 'Some reflections on the breadth and depth of the field of humanitarian logistics and supply chain management'. Journal of Humanitarian Logistics and Supply Chain Management, 2: 2, 108-111.

Tatham, P.H. (2006). 'Meeting the challenge of the 21st century military supply chain - an agenda for research'. Proceedings of the NOFOMA 2006 Conference, Oslo, Norway.

Tatham, P.H. and Pettit, S.J. (2010). 'Transforming humanitarian logistics: The journey to supply network management'. International Journal of Physical Distribution \& Logistics Management, 40: 8.

Tatham, P.H. and Kovács, G. (2010). 'The application of 'swift trust' to humanitarian logistics'. International Journal of Production Economics, 126: 1, 35-45.

Thomas, A.S. and Kopczak, L. (2007). From logistics to supply chain management. Fritz Institute. http://Www.Fritzinstitute.Org/Pdfs/Whitepaper/ Fromlogisticsto.Pdf [Accessed 5 November 2010].

Thomas, A.S. and Mizushima, M. (2005). 'Logistics training: Necessity or luxury?'. Forced Migration Review, 22, 60-61.

Tysseland, B.E. (2007). 'Planning for equipment maintenance and spare parts inventories in manmade humanitarian disasters', in P. Tatham (ed), CD-ROM, Proceedings of the International Humanitarian Logistics Symposium, UK: Faringdon.

United-Nations (2007). Towards a United Nations Humanitarian Assistance Programme for Disaster Response and Reduction: Lessons Learned From the Indian Ocean Tsunami Disaster. Report To The Secretary-General To The General Assembly.

Van Wassenhove, L.N. (2006). 'Humanitarian aid logistics: Supply chain management in high gear'. 
Journal of the Operational Research Society, 57: 5, 475-589.

Vos, F., Rodriguez, J., Below, S. and Guha-Sapir, D. (2010). Annual disaster statistical review, 2009. Centre for Research on the Epidemiology of Disasters. http://Cred.Be/Sites/Default/Files/ Adsr_2009.Pdf [Accessed 25 October 2010].

Walker, H. and Harland, C. (2008). 'E-procurement in the United Nations: Influences, issues and impact'. International Journal of Operations and Production Management, 28: 9, 831-857.

Weeks, M.R. (2007). 'Organizing for disaster: Lessons from the military'. Business Horizons, 50, 479-489.

Weiss, T.G., Campbell, K.M. (1991). 'Military humanitarianism'. Survival, 33, 451-465.
Whipple, J.M. and Russell, D. (2007). 'Building supply chain collaboration: A typology of collaborative approaches'. International Journal of Logistics Management, 18: 2, 174-196.

Whiting, M., Ayala-Ostrom, B. (2009). 'Advocacy to promote logistics in humanitarian aid'. Management Research News, 32, 1081-1090.

Whybark, D.C. (2007). 'Issues in managing disaster relief inventories'. International Journal of Production Economics, 108, 228-235.

Wild, N. and Zhou, L. (2011). 'Ethical procurement strategies for international aid non-governmental organisations'. Supply Chain Management: An International Journal, 16: 2, 110-127. 